BENM 2021

International Scientific and Practical Conference "Biotechnology, Ecology, Nature Management"

\title{
ECOLOGICAL JUSTIFICATION FOR ACCLIMATIZATION OF THE CAUCASIAN BISON IN THE ALTAI NATURE RESERVE
}

\author{
A. Yu. Kondratieva (a)*, A. V. Kozlov (b), I. A. Glebova (c), S. V. Beketov (d) \\ *Corresponding author
}

(a) K.G. Razumovsky Moscow State University of Technologies and Management (the First Cossack University), 73, Zemlyanoy Val str., Moscow, Russia, sylpaticia.anna@gmail.com

(b) K.G. Razumovsky Moscow State University of Technologies and Management (the First Cossack University), 73, Zemlyanoy Val str., Moscow, Russia,

(c) K.G. Razumovsky Moscow State University of Technologies and Management (the First Cossack University), 73, Zemlyanoy Val str., Moscow, Russia

(d) K.G. Razumovsky Moscow State University of Technologies and Management (the First Cossack University), 73, Zemlyanoy Val str., Moscow, Russia, svbeketov@gmail.com

\begin{abstract}
the expansion of the range of the Caucasian bison by introducing small populations into other reserves of Russia, will create prerequisites for confidence in the stability of the existence of the species as a whole. The Altai State Natural Biosphere Reserve can become a promising area for further settlement of Caucasian bison as a wild species and as a hunting resource. The risks associated with the influence of the invasive species on the native flora and fauna are a separate topic for study and we cannot now consider it in sufficient detail. Among artiodactyls common in the Altai Nature Reserve, the red deer and roe deer will most likely have to share their familiar territory with bison. Due to their greater mobility and high adaptability, such a neighborhood will not lead to a noticeable decrease in their numbers. In addition, the inaccessibility of bison for predators is only a visible effect. The Caucasian experience has shown that these large ungulates often become easy prey for predators and are simply subject to death, especially in winter, when snow severely limits both the maneuverability of the entire herd and the mobility of individual animals.
\end{abstract}

2672-8575 (C) 2022 Published by European Publisher.

Keywords: Altai State Nature Biosphere Reserve, Bison bonasus, Caucasian bison 


\section{Introduction}

The wildlife conservation strategy proclaims one of its main goals - the preservation of genetic diversity. Each species has a unique gene pool, formed as a result of natural selection in the process of its evolution. These species have potential economic value, since it is impossible to predict which species will eventually be useful or even irreplaceable for human activities.

Thus, the relevance of the topic is due to the need to develop and implement scientific foundations aimed at further preserving and increasing the number of the species by creating free-breeding populations and further dispersal of bison in the regions of our country.

It took about seventy years of breeding - first in zoological gardens and specialized nurseries, later in nature - in order to increase the number of the world herd of endangered bison from 48 (1927) to 8461 individuals (data at the beginning of 2020). Currently, of them: free - 6244, semi-free - 479 and open-air cages - 1738. The largest number of bison in the world is kept in Poland (2269 individuals), Belarus (2101 individuals), Russia (1588 individuals) and Germany (564 individuals). 6,522 bison are concentrated in these four states, or $77 \%$ of the total world population.

\section{Problem Statement}

Preservation of an endangered species is not an easy and noble task, however, without measures to return it to the wild, without creating or restoring a population, it will remain a half-measure in which the species cannot be considered completely saved from extinction. The restoration of the bison is a vivid example of such a return of the species to its former habitat. This work took place in several stages, the final of which was the transition of animals to complete independence. In the Caucasus, until 1955, a pengrazing system for keeping bison was practiced, combining free grazing on natural pastures with feeding on the territory of two bison parks located on the territory of the Caucasian reserve - Kishinsky and Umpyrsky. Bison appeared in the Umpyr region later: in 1953, 18 bison were brought here from the Chisinau breeding region.

In 1955, the animals were given complete freedom of movement, and they began to independently consistently develop, first, adjacent, then more remote areas of mountain forests. In 1960, the feeding of animals in the winter period was completely stopped. In the same year, tribal records were discontinued (Aleksandrov \& Golgofskaya, 1965).

Thus, the result of colossal human efforts and material costs was the creation of a reproductively independent population of mountain bison (Bison bonasus montanus Rautian, Kalabushkin, Nemtsev 2000) in the upper reaches of the Belaya and Malaya Laba rivers, which are closest to aboriginal (Bison bonasus caucasicus Satunin 1904) in all respects, including their ecosystem role. Currently, the range of mountain bison includes a part of the Caucasian State Natural Biosphere Reserve named after I. Kh. G. Shaposhnikov and adjacent lands on the northern macroslope of the Main Caucasian ridge, located on the territory of the Republic of Adygea, Krasnodar Territory and, insignificantly, the Karachay-Cherkess Republic ("Extermination of game in the mountains ...", 1909; Kalugin, 1969; Nemtsev et al., 2003). This is the largest population of modern bison, which has a complex spatial structure and has existed for decades without any human care. 


\section{Research Methods}

The history of the development of pasture areas by mountain bison is associated with the successive formation of a complex metapopulation structure, including several local populations or territorial groupings, subdivided, in turn, into "ecological groupings" of a lower rank. A variety of physical and geographical conditions, variations in phytocenoses, and the unevenness of anthropogenic impact in different parts of the range formed the ecological originality of each territorial group (Eskina, 2003). The high number of individuals and the large area of the space occupied by them ensured the reproductive independence of each of them. The territorial organization of the bison population, the number of which exceeded 1300 individuals by the end of the 1980s, included 3 categories of animals:

1) bison living year-round in a protected area (half of the population) - represented a reserve part of the livestock, guaranteed against direct extermination, contact with livestock, etc. (Urushten (III) and Umpyr (IV) groupings).

2) territorial groupings existing permanently outside the reserve (at least 250 individuals) ensured a steady increase in the size of the entire population due to high rates of local reproduction (Kunskaya (II) grouping and part of Kishinskaya (I) in the upper reaches of the Sakhrai);

3) nomadic, or migratory, part of the animals, which annually unites up to a third of the total population and maintains the optimal number of bison within the range by means of seasonal migrations (part of the Chisinau grouping that occupies the Shishi valley).

\subsection{Substantiation of the introduction of the Caucasian bison subspecies into the Altai nature reserve}

The preservation of the bison as a species today depends on the possibility of creating large (5001000 and more heads) freely living populations that carry the maximum of the preserved genetic diversity. It is possible to select territories of considerable area suitable for the habitation of bison within its historical range only in Russia (Bashkirov, 1939). We believe that the Altai State Natural Biosphere Reserve can become a promising area for further restoration of the bison as a wild species and as a hunting resource. We said above that an increase in the area directly affects the development of new habitats, and also leads to an increase in the number. The area of the Altai Nature Reserve $(8812 \mathrm{~km} 2)$ is almost three times larger than the area of the Caucasian Nature Reserve $(2848 \mathrm{~km} 2)$, which gives broad prospects for the creation of the largest population of bison in the world there.

The Caucasian subspecies of bison has a big plus in that these animals are well adapted to life in mountain conditions, both physically and socially. They are hardy enough to walk on mountain trails and the structure of the hoof horn allows for crossings on rocky ground. In addition, populations of bison in the Caucasus make seasonal migrations - in winter to areas with little snow, and in summer to cooler elevated areas. However, in general, the territory of the Altai reserve is located in more severe climatic conditions than the Caucasian one. Let's dwell on this point in more detail. 


\subsection{Compliance with climatic conditions}

The climate of the reserve is mountainous-continental and strongly depends on the features of the relief. The reserve is located in the central part of the mainland, where the anticyclones of Asia and the air masses of the Arctic mainly affect the weather conditions. Summer is cool due to the elevated position of the reserve, it is absent on the mountain peaks. It is humid in the north, drier in the south. In the southern part of the reserve there are valleys of Lake Teletskoye and the Chulyshman River; this area is characterized by mild winters and cool short summers. There is practically no snow here, the total amount of precipitation per year is about $500 \mathrm{~mm}$. An important point for us is that winter on the shores of Lake Teletskoye is one of the mildest in Siberia, which is associated with the influence of the eastern and southeastern fenns, which are common at this time of the year. Nowhere else in our country do hair dryers have such a softening effect on the winter as in Altai.

In the northern part of the reserve, where the mid-mountain zone of the taiga is located, on the contrary, winters are mostly cold and snow already falls at the end of October. Summer air temperature reaches $+30^{\circ} \mathrm{C}$. Annual precipitation is approximately $900 \mathrm{~mm}$.

\section{Findings}

We believe that it is in the southern part, in the valley of Lake Teletskoye and the Chulyshman River, due to the most suitable (habitual) climate, that a bison park with the first batch of immigrants of 30-40 heads should be located. Further, within 4-5 years, adhering to the "Caucasian" scheme of adaptation of bison, give the animals the opportunity to explore and develop the adjacent territories. Further, upon confirmation of the success of the project, the number of groups in the bison nursery can be increased to 200-300 heads by transporting new batches of bison from the Caucasian Reserve.

Preparatory measures before the introduction of a new species into the territory where rare, Red Book, relict animals and plants live, requires a thorough study of the biological characteristics of both the objects of introduction and the native flora and fauna. Mammals of the Altai region are represented by 70 species, the most numerous in the protected area are sable, maral, musk deer, and bear (Nikolsky et al., 2013). The international Red Book includes the snow leopard, Altai mountain sheep, Siberian musk deer. In the forests near Lake Teletskoye, you can find several varieties of rare representatives of bats: the brown long-eared bat, the baleen bat, the red noch, Brandt's bat and others that live only in the landscapes of the reserve and are listed in the Altai Red Book. There are 1,500 species of plants, 136 species of mushrooms, 272 species of lichen, about 700 species of algae. Among all plant diversity - 22 are in the Red Book of Russia.

\section{Conclusion}

The risks associated with the influence of the invasive species on the native flora and fauna are a separate topic for study and we cannot now consider it in sufficient detail. Let us dwell on only two aspects that, in our opinion, are most relevant for the introduction of large ungulates into a new territory. 
1) Competition with other species of wild ungulates - aborigines and species introduced earlier for grazing resources. Possible options for other ungulate species to get "between a rock and a hard place" are competition on pastures from bison and increased (as a result) pressure from local predators. Among artiodactyls common in the Altai Nature Reserve, the red deer and roe deer will most likely have to share their familiar territory with bison. Due to their greater mobility and high adaptability, such a neighborhood will not lead to a noticeable decrease in their numbers. In addition, the inaccessibility of bison for predators is only a visible effect. The Caucasian experience has shown that these large ungulates often become easy prey for predators and are simply subject to death, especially in winter, when snow severely limits both the maneuverability of the entire herd and the mobility of individual animals.

2) The influence of clusters of bison groups (seasonal pasture migrations, wintering ...) as a possible pressure factor on the limited area of rare, Red Book plants. Moreover, this pressure may not be the result of grazing, but trampling. The Red Book contains 22 plant species of the region. This is a relatively small number and, if necessary, each of them can be studied further in terms of possible pressure from the invaders. Here we will only note that when the bison is introduced, it will share the land with the also rather large ungulates, in many ways similar to them in their habits - red deer, roe deer, elk. The same trails, pastures and watering places. Therefore, we can assume that when a bison is introduced, an undesirable load on rare plant communities will not occur (Dyrenkov et al.,1990).

In conclusion of this brief overview of the possible risks of acclimatization in our article, we would like to present the main argument in favor of a "harmless" bison - an invader. It is a large and highly visible animal, making the new population relatively easy to control. It will not be difficult for a person to reduce or remove it, especially since there were already plenty of such facts in the history of the wild bison.

\section{References}

Aleksandrov, V. N., \& Golgofskaya, K. Y. (1965). Forage lands of the bison of the Caucasian Reserve. Proceedings of the Caucasian State Reserve, 129-154.

Bashkirov, I. S. (1939). Caucasian European bison. Main Directorate of Reserves, Forest Parks and Zoological Gardens, Council of People's Commissars of the RSFSR.

Dyrenkov, S. A., Golgofskaya, K. Y., \& Nemtsev A. S. (1990). European bison and their influence on vegetation. Biogenic successions. Voprosy biogeocenology, 96-151.

Eskina, T. G. (2003). On the environment-forming role of the mountain bison. Problems of ecology of mountain territories. Sat. scientific. Proceedings of IEGT KBSC RAS. Nalchik, 54-55.

Extermination of game in the mountains of the Kuban region. (1909). Nature and hunting. October and November, 69-78.

Kalugin, S. G. (1969). Bison of the North-Western Caucasus. Abstract of dis. Zool. Institute of the USSR Academy of Sciences. Scientist. Advice. - Maykop.

Nemtsev, A. S., Rautian, G. S., Puzachenko, A. Y., Sipko, T. P., Kalabushkin, B. A., \& Mironenko, I. V. (2003). Bison in the Caucasus. ed. Rautian G.S. Maykop: Quality.

Nikolsky, A. A., Rozhnov, V. V., Poyarkov, A. D., Mikheev, A. V., \& Yachmennikova, A. A. (2013). Biological signaling field of mammals. In A. A. Nikolsky, \& V. V. Rozhnov (Eds.), Collective monograph. KMK Scientific Publishing Association. 